Review Article

\title{
The Complicated Body in Motion: Rediscovering the Mechanical Stimulations in Cell Models of Human Disease
}

Tzyy-Yue Wong ${ }^{1,2}$, Yu-Kai Tseng ${ }^{3,4}$, Tung-Chen Yeh ${ }^{5}$, Rong-Chang Jhong ${ }^{2}$, Yue-Fang Wang ${ }^{2}$, Hui-Yu Chang ${ }^{2}$, Pei-Wen Cheng ${ }^{2,6,7 *}$.

${ }^{1}$ Research Assistant Center, Show Chwan Health Memorial Hospital, Changhua, Taiwan

${ }^{2}$ Department of Education and Research, Kaohsiung Veterans General Hospital, Kaohsiung, Taiwan

${ }^{3}$ Department of Medical Research, Chang Bing Show Chwan Health Memorial Hospital, Changhua, Taiwan

${ }^{4}$ Department of Orthopedics, Show Chwan Memorial Hospital, Changhua, Taiwan

${ }^{5}$ Department of Internal Medicine, Division of Cardiology, Kaohsiung Veterans General Hospital, Kaohsiung, Taiwan

${ }^{6}$ Yuh-Ing Junior College of Health Care and Management, Kaohsiung, Taiwan

${ }^{7}$ Shu-Zen Junior College of Medicine and Management, Kaohsiung, Taiwan

*Correspondence: pwcheng@vghks.gov.tw (P.-W.C.); Tel.: 886-7-3422121 ext. 1593 (P-W.C).

\begin{abstract}
Thought runs through the mind like blood runs through our body to keep us alive. Like the mind, the body does not stay inert and is in constant motion. Not a single cell in our body is left inert unless cell is under stress or dying. These scenarios are reflected upon when a person is sick, the person lies in bed with less movement; however, is active when the person is healthy. The topic of mechanical stimulation has emerged due to the increasing understanding of the physical stimulations we face each day. Further understanding of the mechanically-regulated mechanism can help us explore the pathological events in a disease. Here, we reviewed the role of sensory proteins in pathological events that are observed in cardiomyopathy, cancer, respiratory, renal, obesity, genetics, physical injury and bacterial infection. Taken together, sensory proteins are mechanically-activated which assist reception of external physical stimulation and convert into biochemical to trigger intracellular signaling cascade.
\end{abstract}

Keywords: Motion; Inert; Mechanical stimulation; Sensory proteins. 


\section{Introduction}

\section{The challenge of simulating mechanical stimulation as in vivo}

In a healthy lifestyle, regular exercises are preferred over a sedentary lifestyle which may result to weight gain, weaken muscles, lower sense of well-being, and low self-esteem. Clinically, patients with difficulty in movement can be improved through exercising as in rehabilitation. In a vegetative state, individuals retain the desire to move despite being unable to move voluntarily. From a macroscopic view, biological entity requires movement, or physical stimulation in nature.

The challenge of simulating the dynamics as in vivo requires recapitulation of the external physical force and the cellular microenvironment. The cellular microenvironment represents a tiny unit of our entire body, receiving physical stimulations for normal function from the extracellular space. In this review, we summarized current research on the function of mechanical stimulations in human disease, and examined the types of mechanical stimulation for simulating the disease.

\section{Sensory proteins}

The physical force is sensed by the cells through a network of sensory proteins or mechanically-activated proteins such as G protein-coupled receptors (GPCRs) or ion channels which transmit the signal intracellularly ${ }^{1}$ (Figure 1). Inside the cell, several types of proteins are activated, causing conformational change, protein-protein interaction $^{2}$. In some cases, the intracellular signal is transduced into cell nucleus for transcriptional regulation. The major types of physical forces are compression, stretching, hydraulic pressure, and so forth. The physical forces are converted into electrical or biochemical signals. 


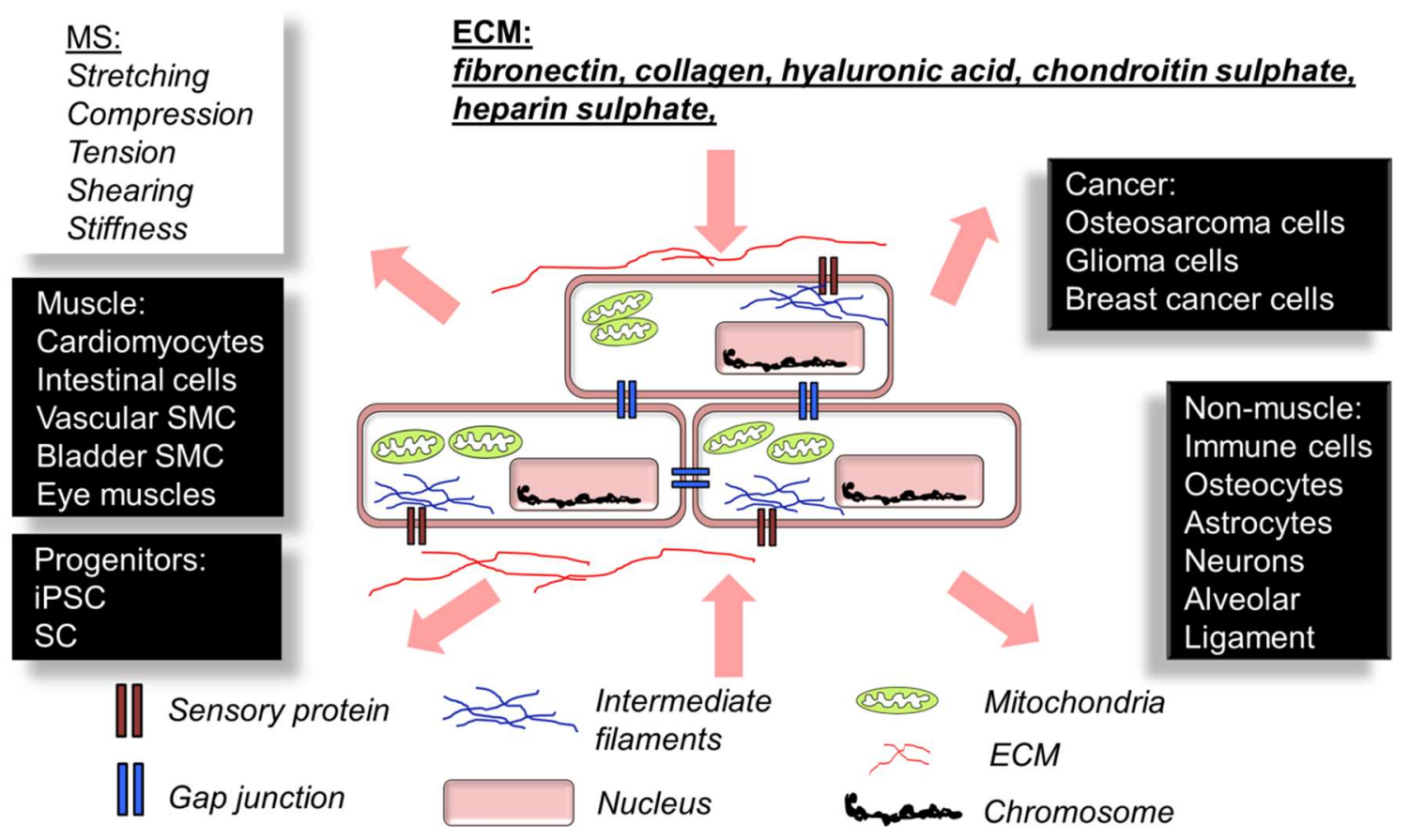

Figure 1. Illustration depicting the major components that sense mechanical stimulation in the in vivo microenvironment. The cells utilize sensory protein in the cell membrane to detect mechanical stimulations in the extracellular space which is filled with ECM. Through the sensory protein, mechanical signals are converted into biochemical signals through reorganization of cytoskeletal proteins which can transduce signal into cell nucleus to recruit transcriptional co-activators such as YAP/TAZ for gene regulation. The major types of cells that are known to experience MS in their microenvironment are: cancer cells, muscle, non-muscle cells, and progenitor cells. Abbreviations: MS: Mechanical stimulation; ECM: Extracellular matrix; SMC: Smooth muscle cells; iPSC: induced-pluripotent stem cells; SC: stem cells.

For instance, the physical stimulations are converted into electrical signals as our hearing and sense of touch ${ }^{3}$. The Drosophila sound-sensitive neurons express the ion channel NompC for transducing mechanical stimulation signal during hearing ${ }^{4}$. The physical presence of foods, odors, and sights are changed into biochemical signals as our tastes, smells, and vision, respectively ${ }^{5}$. The two types of proteins that receive or sense the physical stimulations are ion channels and G protein-coupled receptors (GPCRs) ${ }^{6}$. The proteins that sense these physical stimulations are called sensory proteins. For physical stimulations to be converted into either biochemical or electrical, the cells require expression of sensory genes. For example, the sensory gene rhodopsin is expressed in the retina cells of the eye, producing the GPCR that is conjugated to chromophore. Upon sensation of physical light stimulation, the GCPR is activated by light photons, initiating a biochemical cascade. 


\section{Mechanical stimulations sensed by various types of cells}

The cells of different organs differ from one another in that they have different functions (Figure 1). Nonetheless, different cells can sense the same physical stimulation. For example, the eyes see light through sensing light photons, the skin sense the light through detecting warmth caused by light photons. Another example is the ear senses sound through vibration waves, the hand senses sound through vibrating medium or object ${ }^{7}$. Inside our body, the cells sense the beating heart, proclamation of its living status. The change in the heart rate would be sensed by other cells in the body, sending out an alarm in case of a sudden increase in heart pressure. Apelin receptor (APJ), a kind of GPCR expressed in the heart, is associated with cardiac hypertrophy, and heart failure ${ }^{8}$.

Apart from the heart which is the dynamic center of being alive, other major organs such as the lungs also receive and experience physical stimulation ${ }^{9}$. As we breathe, the alveolar cells in the lungs expand, and relax as we breathe out. Sometimes overbreathing due to exercise might cause shortness of breath due to insufficient lung capacity. In other words, the lungs cannot provide enough fresh air at the required amount of time. However, over-breathing might not cause any visible or detrimental health problems. In patients who are on ventilator for breathing support, the consequence is more prominent. Many previous studies have reported that patients` lungs are literally injured by the mechanically-controlled ventilator. Mechanical stretching plays an critical part in maintaining lung structure ${ }^{10}$; however, due to over-stretching of the lungs, the alveolar type 2 cells produce less amount of surfactant which could protect the lungs from inflammation and injury 9 .

Apart from physical stimulations that seem to originate from the external surrounding, there are those that originate from within the organs such as the intestinal movement, uterus contraction, blood pressure within blood vessels, bladder pressure, liver, and so forth. The blood vessels provide the body warm temperature, as well as fresh air through oxygen carrier, the red blood cells. However, blood vessels are not just fresh air provider, but also carry nutrients and required stem cells and hormones throughout the body. The structures of blood vessels are found to express stretch-activated ion channels (SAC) known as Piezo. The Piezo is expressed on endothelial cell membrane which can sense the pressure exerted by blood pressure onto the walls.

Despite the fact that brain neurons seem to have no motion and do not receive physical stimulation as dynamic as the beating heart at any given time, the SAC Piezo1 and Piezo2 were first found in neuronal cells called N2A cells ${ }^{11}$. It is plausible to speculate that the neurons are not in dynamic but still require sensory proteins to sense their surroundings. The neurons detect mechanical stimulation by converting the 
stimulation into biochemical signaling, changing the organization of intermittent filament inside the cells $\mathrm{s}^{1-2}$. The protein Piezol has been found to be expressed in human cardiomyocytes and responded to cyclic stretching ${ }^{12}$. In the digestive tract, movement is important for digesting foods. The contraction and relaxation of intestinal muscle cells is found to enhance differentiation of progenitor cells, and also promote food digestion through calcium ion level increase via Piezo ${ }^{13}$.

Furthermore, the liver is a major organ that is relatively less motile compared to the beating heart. Despite the fact that liver is less dynamic in nature, it is covered with immense amount of blood vessels through the hepatic portal artery and vein. In normal liver, the stellate cells are quiescent, residing in G0 phase of cell cycle. However, previous study showed that mechanical stimulation such as stretching can activate the stellate cells, differentiating into myofibroblasts which lead to liver fibrosis ${ }^{14}$. Furthermore, the blood vessels carry blood, thereby it is pulsatile with certain amount of pressure pressing against the blood vessel walls. Therefore, the liver is filled with dynamic of pulsating blood vessels.

\section{Mechanical properties in 2D and 3D cell model}

The current challenge in creating cell model that closely resembles in vivo is finding the suitable 3D scaffold that sustains mechanical stimulations. Evidence showed that mechanical stimulation has various beneficial effects on the cells being stretched. The reason is because cells have mechanical properties in which they respond to maintain normal functions. In vivo, the 3D microenvironment is filled with several major types of extracellular matrices such as collagen, fibronectin, hyaluronic acid, chondroitin sulphate and heparin sulfate ${ }^{15}$. Stretching is found to enhance angiogenesis, cell proliferation, as well as stem cells homing. In dentistry, orthodontal force or stretching is used to pull teeth so that dental stem cells, periodontal stem cells at the root of the teeth can be activated ${ }^{16}$. The mechanically-activated stem cells can become bone cells which might involve GTP-binding protein such as Rho ${ }^{17}$, filling in the empty spaces in the tooth cavity. In vitro studies have found that mechanical stretching can promote stem cells growth ${ }^{18}$. Furthermore, the expanded stem cells can have clinical applications because of larger in cell number.

The greatest challenge in assessing disease as complicated as cancer is the growth of cancerous tissue or tumor. In vivo, the tumor grows into a detectable size, becomes a scar that is difficult to be cured. With the detectable size, the tumor also has stiffness that is usually higher compared to normal tissue ${ }^{19}$. In vitro experiments have shown that change in stiffness can alter cell proliferation, even promote cancer growth. Adding to the mechanical property of cells, including the cancer cells, the tumor stiffness itself is 
promoting tumor growth ${ }^{20}$. Ideas have begun to emerge that tumor growth might be affected when the sensory proteins in the cancer cells were inhibited. As a result, the use of 3D scaffold combined with a mechanical stimulation has become a major focus in recent cancer study. Furthermore, cancer study by organoid culture requires a 3D shape, in short, a depth to the culture system. Since previous study showed that stiffness of tumor is correlated to metastatic grade, the depth in $3 \mathrm{D}$ is believed to better mimic in vivo microenvironment, so is the mechanical property of cells ${ }^{21}$. In $2 \mathrm{D}$ culture, the mechanical property of cells is manifested by cell tension through adhesion onto the culture surface, and often void of any mechanical stimulation. As mentioned before, the mechanical stimulations are converted into signals in the cells through sensory proteins. It is plausible to speculate that non-dynamic culture system is unable to exert the function of sensory proteins when compared to culture supplied with mechanical stimulation.

\section{Mechanical properties of diseased microenvironment}

To investigate the role of mechanical stimulation, the pathological events such as angiogenesis, inflammation, epithelial-to-mesenchymal transition (EMT), hypertrophy, hypertension, cell death, and so on have been focused (Table 1). Many of these pathological events are affected by mechanical stimulation, thereby understanding the role of mechanical stimulation in disease can help find a cure.

Table 1. Mechanical cues manifestation in various pathological events.

\begin{tabular}{|c|c|c|c|c|}
\hline & Disease/ Injury & $\begin{array}{l}\text { Pathological } \\
\text { events }\end{array}$ & $\begin{array}{l}\text { Mechanisms related to mechanical } \\
\text { stimulation }\end{array}$ & Ref. \\
\hline \multirow[t]{3}{*}{1} & \multirow[t]{3}{*}{ Cardiomyopathy } & Hypertrophy & $\begin{array}{l}\text { Cardiac hypertrophy requires APJ sensory } \\
\text { protein }\end{array}$ & 28 \\
\hline & & Hypertension & $\begin{array}{l}\text { 1. Vascular architecture development requires } \\
\text { SAC Piezo1 in the arterial wall } \\
\text { 2. Remodeling of arterial wall due to increased } \\
\text { blood pressure requires Piezol regulation }\end{array}$ & 22 \\
\hline & & Failure & $\begin{array}{l}\text { Stretched-induced angiotensinogen (Ageon) is } \\
\text { regulated by p38 } \alpha \text { MAPK through pJNK down- } \\
\text { regulation }\end{array}$ & 29 \\
\hline \multirow[t]{3}{*}{2} & \multirow[t]{3}{*}{ Cancer } & Cell migration & $\begin{array}{l}\text { The stiffness in cell-to-ECM interaction during } \\
\text { cancer progression enhances cell migration } \\
\text { through invadopodia }\end{array}$ & $19-20$ \\
\hline & & Cell invasion & $\begin{array}{l}\text { Breast cancer cell migration is enhanced by } \\
\text { compressive force }\end{array}$ & 30 \\
\hline & & Angiogenesis & $\begin{array}{l}\text { Angiogenesis is enhanced by cyclic stretching } \\
\text { which also aligns the endothelial sprouts } \\
\text { perpendicular to the stretching force }\end{array}$ & 31 \\
\hline
\end{tabular}




\begin{tabular}{|c|c|c|c|c|}
\hline & Disease/ Injury & $\begin{array}{l}\text { Pathological } \\
\text { events }\end{array}$ & $\begin{array}{l}\text { Mechanisms related to mechanical } \\
\text { stimulation }\end{array}$ & Ref. \\
\hline & & Fibrosis & $\begin{array}{l}\text { Hepatic stellate cells undergo fibronectin fibril } \\
\text { assembly through direct effects of thrombi and } \\
\text { mechanical strain which drives hepatic fibrosis }\end{array}$ & 32 \\
\hline & & $\begin{array}{l}\text { Muscle } \\
\text { wasting }\end{array}$ & $\begin{array}{l}\text { Lewis lung carcinoma cell conditioned medium } \\
\text { decreases mTORC1, protein synthesis signaling } \\
\text { in stretched myotubes }\end{array}$ & 33 \\
\hline & & EMT & $\begin{array}{l}\text { Mechanical ventilation increases lung } \\
\text { hydroxyproline and the mesenchymal markers } \\
\alpha \text {-SMA and Vimentin in mice }\end{array}$ & 34 \\
\hline & & ECM rigidity & $\begin{array}{l}\text { MSC differentiation requires tension from ECM } \\
\text { stiffness to upregulate YAP/TAZ }\end{array}$ & 35 \\
\hline \multirow[t]{2}{*}{3} & \multirow[t]{2}{*}{ Respiratory } & Bronchi & $\begin{array}{l}\text { Mechanical stress resulted from lung inflation in } \\
\text { human bronchi tissue led to leukotriene-E4 } \\
\text { increase, an inflammatory factor }\end{array}$ & 36 \\
\hline & & Lung inflation & $\begin{array}{l}\text { Piezo2 over-expression in sensory neuron } \\
\text { causes apnoea in mice }\end{array}$ & 37 \\
\hline \multirow[t]{2}{*}{4} & \multirow[t]{2}{*}{ Renal } & Renal fibrosis & $\begin{array}{l}\text { Stretching of renal tubular epithelial cells } \\
\text { increases Pyk } 2 \text { which is associated to renal } \\
\text { fibrosis in mice }\end{array}$ & 38 \\
\hline & & $\begin{array}{l}\text { Ureteral } \\
\text { obstruction }\end{array}$ & $\begin{array}{l}\text { Stretching of mouse proximal tubule and } \\
\text { collecting duct cells cause apoptosis }\end{array}$ & 39 \\
\hline \multirow[t]{2}{*}{5} & \multirow[t]{2}{*}{ Obesity } & Fat tissue & $\begin{array}{l}\text { Mechanical stimulation with a } 5 \text {-hour refractory } \\
\text { period decreases TNF- } \alpha \text { gene expression and } \\
\text { mitigates obesity-triggered fatty tissue } \\
\text { dysfunction in mice }\end{array}$ & 40 \\
\hline & & Diabetes & $\begin{array}{l}\text { Static, passive muscle stretching lowers blood } \\
\text { glucose }\end{array}$ & 41 \\
\hline \multirow[t]{2}{*}{6} & \multirow[t]{2}{*}{ Genetics } & Aneuploidy & $\begin{array}{l}\text { Neuroblast of Drosophila elongates or stretches } \\
\text { to avoid aneuploidy through preventing } \\
\text { cytokinesis failure }\end{array}$ & 42 \\
\hline & & $\begin{array}{l}\text { Abnormal } \\
\text { muscle } \\
\text { development }\end{array}$ & $\begin{array}{l}\text { Muscle development in C. elegans requires } \\
\text { muscle-induced tension to sustain PAK-1 and } \\
\text { PIX-1 expressions }\end{array}$ & 43 \\
\hline \multirow[t]{4}{*}{7} & \multirow[t]{4}{*}{ Physical injury } & Cell death & $\begin{array}{l}\text { Stretch-induced traumatic brain injury model } \\
\text { increases intracellular calcium and cell death }\end{array}$ & 44 \\
\hline & & Inflammation & $\begin{array}{l}\text { Stretching for } 10 \text { minutes, twice every day } \\
\text { reduces inflammation in rats }\end{array}$ & 45 \\
\hline & & $\begin{array}{l}\mathrm{ECM} \\
\text { remodeling }\end{array}$ & Stress in ECM activates latent TGF- $\beta 1$ & 46 \\
\hline & & $\begin{array}{l}\text { Delayed } \\
\text { wound healing }\end{array}$ & $\begin{array}{l}\text { Shear stress by fluid flow triggers TGF- } \beta 1 \\
\text { release causes delayed wound healing in human } \\
\text { corneal epithelial cells }\end{array}$ & $23 \mathrm{a}$ \\
\hline
\end{tabular}




\begin{tabular}{|l|l|l|l|l|}
\hline & Disease/ Injury & $\begin{array}{l}\text { Pathological } \\
\text { events }\end{array}$ & $\begin{array}{l}\text { Mechanisms related to mechanical } \\
\text { stimulation }\end{array}$ & Ref. \\
\hline 8 & $\begin{array}{l}\text { Bacterial } \\
\text { infection }\end{array}$ & $\begin{array}{l}\text { Mitochondrial } \\
\text { fission }\end{array}$ & $\begin{array}{l}\text { Mechanical stress caused by bacterial infection } \\
\text { leads to mitochondrial fission }\end{array}$ & 47 \\
\hline
\end{tabular}

Abbreviations: APJ: Apelin receptor; mTORC1: mammalian target of rapamycin complex 1; YAP: yes-associated protein 1; TAZ: Tafazzin; Pyk2: Pyruvate kinase 2; Piezo: Piezo Type Mechanosensitive Ion Channel Component; MAPK: Mitogen-activated protein kinase; pJNK: phosphorylated c-Jun N-terminal kinase; EMT: Epithelial-to-mesenchymal transition; PAK-1: P21 (RAC1) Activated Kinase 1; PIX-1: PAK (p21-activated kinase) Interacting eXchange factor; TNF- $\alpha$ : Tumor necrotic factor-alpha.

Starting from the heart, the GPCR APJ senses the increased cardiac pressure which could enhance hypertrophy. However, when the APJ is knocked out, hypertrophy is inhibited ${ }^{8 a}$. Supporting the role of sensory protein in cardiac disease is remodeling of blood vessel structure during hypertension through the Piezol protein ${ }^{22}$. Secondly, in cancer, mechanical stimulation might cause accumulation of collagen which promotes fibrosis and inflammation. The stretched collagen is found to activate TGF- $\beta 1$, and is released from the collagen matrix to further stimulate cells ${ }^{23}$. The cells stimulated by TGF- $\beta 1$ might promote further TGF- $\beta 1$ release. Furthermore, higher level of exercising has been linked to reduced circulating cancer cells ${ }^{24}$, thereby leading to decreased metastasized tumor growth. From the point of view of immune system, mechanical stimulation might affect the immune cells through activation of macrophage. It is speculated that activated macrophage might be associated with a stepped-up immune system, therefore, a stronger immune system. The hypothesis is that physical stimulation through exercising affects our health at molecular level.

In general, a healthy individual is encouraged to maintain certain level of exercise all the time. The scientific reason behind this is that exercising the cells can affect cell metabolism. In vitro, mechanical stimulation can disrupt function of fat cells. In vivo, mechanical stimulation leads to dysfunctional fat tissue in mice. At macroscopic level, lack of movement is associated with pressure ulcer development which is a form of inflammation. However, excessive exercise might cause negative effects on the cells. Instead of converting physical stimulation into intracellular signals, the sensory proteins might be overloaded with increased physical stimulation. The overloaded cells might undergo apoptosis or have the pain sensation through stimulated neurons. The signaling pathway of pain in neurons has been attributed to neurotransmitter through amyloid beta fiber in sensory neurons, or through myelinated afferents and activation of NK-1 receptor to the spinal cord where pain sensation is sent to the brain ${ }^{25}$. Here, mechanically- 
activated ion channels such as Piezo1, and non-mechanically-activated ion channels such as TRPV1 are expressed in the neurons. However, the role of these mechanicallyactivated ion channels in the pain sensation requires further investigation.

Our daily life is filled with surprises of mechanical stimulation that can be of accidental. The accidents may cause physical injuries to our skin, brain, or any organs. To heal the wound, scientists have investigated the use of tension to encourage cell regeneration through promoting mesenchymal stem cells homing ${ }^{26}$. In vitro study showed that stretching force modulates integrin to promote fibrosis during scar formation ${ }^{27}$. Therefore, it is important to convey the amount of mechanical force to minimize scar formation. Since it is known that physical stimulation affects cells at molecular level, rehabilitation can be further improved through modulating the cells at gene level. Thus, the emerging trend in rehabilitation in recent years is mechanotherapy.

\section{Concluding remarks}

In recent years, 3D with additional mechanical stimulation culture system has been the rising trend in basic research. With advancement of knowledge in mechanical stimulations, technology for simulating the natural physical forces can be performed in the laboratory. The types of natural forces for mechanical simulation can be categorized into five main groups: 1. Cyclic stretching; 2. Passive stretching; 3. Cyclic compression; 4. Passive compression; 5. Shearing by fluid. New study in the future regarding diseased microenvironment needs to incorporate these mechanical stimulations into their models. Scaffolds that are stretchable are increasingly important for development of cell model because of the structure and architecture, the depth that is not available in 2D culture system. In summary, mechanical stimulations play important role in biological systems. 


\section{Acknowledgements}

We would like to give special thanks to TAIHOYA (Kaohsiung, Taiwan) for ideas in mechanical stimulation technology.

\section{Author contributions}

Conceptualization and writing of this manuscript were contributed by Tzyy-Yue Wong; Yu-Kai Tseng and Tung-Chen Yeh were supportive of the mechanical stimulation ideas from many aspects, including conceptualization; Rong-Chang Jhong, Yue-Fang Wang, and Hui-Yu Chang were responsible for references gathering and organization; Pei-Wen Cheng carried out review and editing work.

\section{Funding}

There is no funding for this manuscript preparation.

\section{Conflict of interest}

The authors in this study declared no competing interests. 


\section{References}

1. Johnson, W. A., Two views of the same stimulus. elife 2017, 6, e30191.

2. Harris, A. R.; Jreij, P.; Fletcher, D. A., Mechanotransduction by the Actin Cytoskeleton: Converting Mechanical Stimuli into Biochemical Signals. Annual Review of Biophysics 2016, 47 (1), 617-631.

3. Geppetti, P.; Veldhuis, N. A.; Lieu, T.; Bunnett, N. W., G Protein-Coupled Receptors: Dynamic Machines for Signaling Pain and Itch. Neuron 2015, 88 (4), 635-49.

4. Kamikouchi, A.; Inagaki, H. K.; Effertz, T.; Hendrich, O.; Fiala, A.; Göpfert, M. C.; Ito, K., The neural basis of Drosophila gravity-sensing and hearing. Nature 2009, 458, 165.

5. Connelly, T.; Yu, Y.; Grosmaitre, X.; Wang, J.; Santarelli, L. C.; Savigner, A.; Qiao, X.; Wang, Z.; Storm, D. R.; Ma, M., G protein-coupled odorant receptors underlie mechanosensitivity in mammalian olfactory sensory neurons. Proceedings of the National Academy of Sciences 2015, $112(2), 590$.

$6 . \quad J u l i u s$, D.; Nathans, J., Signaling by sensory receptors. Cold Spring Harbor perspectives in biology 4 (1), a005991-a005991.

7. (a) Ren, T.; He, W.; Li, Y.; Grosh, K.; Fridberger, A., Light-induced vibration in the hearing organ. Scientific Reports 2014, 4, 5941; (b) El Hady, A.; Machta, B. B., Mechanical surface waves accompany action potential propagation. Nature Communications 2015, 6, 6697.

8. (a) Scimia, M. C.; Hurtado, C.; Ray, S.; Metzler, S.; Wei, K.; Wang, J.; Woods, C. E.; Purcell, N. H.; Catalucci, D.; Akasaka, T.; Bueno, O. F.; Vlasuk, G. P.; Kaliman, P.; Bodmer, R.; Smith, L. H.; Ashley, E.; Mercola, M.; Brown, J. H.; Ruiz-Lozano, P., APJ acts as a dual receptor in cardiac hypertrophy. Nature 2012, 488 (7411), 394-398; (b) Wang, J.; Gareri, C.; Rockman Howard, A., GProtein-Coupled Receptors in Heart Disease. Circulation Research 2018, 123 (6), 716-735.

9. Liu, M.; Tanswell, A. K.; Post, M., Mechanical force-induced signal transduction in lung cells. American Journal of Physiology-Lung Cellular and Molecular Physiology 1999, 277 (4), L667-L683.

10. (a) Sanchez-Esteban, J.; Cicchiello, L. A.; Wang, Y.; Tsai, S.-W.; Williams, L. K.; Torday, J. S.; Rubin, L. P., Mechanical stretch promotes alveolar epithelial type II cell differentiation. Journal of Applied Physiology 2001, 91 (2), 589-595; (b) Edwards, Y. S., Stretch stimulation: its effects on alveolar type II cell function in the lung. Comparative biochemistry and physiology. Part $A$, Molecular \& integrative physiology 2001, 129 (1), 245-60.

11. Coste, B.; Mathur, J.; Schmidt, M.; Earley, T. J.; Ranade, S.; Petrus, M. J.; Dubin, A. E.; Patapoutian, A., Piezo1 and Piezo2 are essential components of distinct mechanically activated cation channels. Science (New York, N.Y.) 2010, 330 (6000), 55-60.

12. Wong, T.-Y.; Juang, W.-C.; Tsai, C.-T.; Tseng, C.-J.; Lee, W.-H.; Chang, S.-N.; Cheng, P.-W., Mechanical Stretching Simulates Cardiac Physiology and Pathology through Mechanosensor Piezo1. Journal of clinical medicine 2018, 7 (11), 410.

13. He, L.; Si, G.; Huang, J.; Samuel, A. D. T.; Perrimon, N., Mechanical regulation of stemcell differentiation by the stretch-activated Piezo channel. Nature 2018, 555 (7694), 103-106.

14. Olsen, A. L.; Bloomer, S. A.; Chan, E. P.; Gaça, M. D. A.; Georges, P. C.; Sackey, B.; Uemura, M.; Janmey, P. A.; Wells, R. G., Hepatic stellate cells require a stiff environment for myofibroblastic differentiation. American journal of physiology. Gastrointestinal and liver physiology 2011, 301 (1), G110-G118.

15. (a) Wong, T. Y.; Chang, C.-H.; Yu, C.-H.; Huang, L. L. H., Hyaluronan keeps mesenchymal stem cells quiescent and maintains the differentiation potential over time. Aging cell 2017, 16 (3), 451-460; (b) Solis, M. A.; Chen, Y.-H.; Wong, T. Y.; Bittencourt, V. Z.; Lin, Y.-C.; Huang, L. L. H., Hyaluronan regulates cell behavior: a potential niche matrix for stem cells. Biochemistry 
research international 2012, 2012, 346972-346972; (c) Wong, T. Y.; Chen, Y.-H.; Liu, S.-H.; Solis, M. A.; Yu, C.-H.; Chang, C.-H.; Huang, L. L. H., Differential Proteomic Analysis of Human PlacentaDerived Mesenchymal Stem Cells Cultured on Normal Tissue Culture Surface and HyaluronanCoated Surface. Stem cells international 2016, 2016, 2809192-2809192; (d) Wong, T. Y.; Solis, M. A.; Chen, Y.-H.; Huang, L. L.-H., Molecular mechanism of extrinsic factors affecting anti-aging of stem cells. World journal of stem cells 2015, 7 (2), 512-520.

16. Meeran, N. A., Cellular response within the periodontal ligament on application of orthodontic forces. Journal of Indian Society of Periodontology 2013, 17 (1), 16-20.

17. Basdra, E. K., Biological reactions to orthodontic tooth movement. Journal of orofacial orthopedics = Fortschritte der Kieferorthopadie : Organ/official journal Deutsche Gesellschaft fur Kieferorthopadie 1997, 58 (1), 2-15.

18. Clause, K. C.; Liu, L. J.; Tobita, K., Directed stem cell differentiation: the role of physical forces. Cell communication \& adhesion 2010, 17 (2), 48-54.

19. Northcott, J. M.; Dean, I. S.; Mouw, J. K.; Weaver, V. M., Feeling Stress: The Mechanics of Cancer Progression and Aggression. Frontiers in cell and developmental biology 2018, 6, 17-17.

20. Gasparski, A. N.; Ozarkar, S.; Beningo, K. A., Transient mechanical strain promotes the maturation of invadopodia and enhances cancer cell invasion \&lt;em\&gt;in vitro\&lt;/em\&gt. Journal of Cell Science 2017, 130 (11), 1965.

21. Swaminathan, V.; Mythreye, K.; O'Brien, E. T.; Berchuck, A.; Blobe, G. C.; Superfine, R., Mechanical stiffness grades metastatic potential in patient tumor cells and in cancer cell lines. Cancer research 2011, 71 (15), 5075-5080.

22. Retailleau, K.; Duprat, F.; Arhatte, M.; Ranade, S. S.; Peyronnet, R.; Martins, J. R.; Jodar, M.; Moro, C.; Offermanns, S.; Feng, Y.; Demolombe, S.; Patel, A.; Honore, E., Piezo1 in Smooth Muscle Cells Is Involved in Hypertension-Dependent Arterial Remodeling. Cell Rep 2015, 13 (6), 1161-1171.

23. (a) Utsunomiya, T.; Ishibazawa, A.; Nagaoka, T.; Hanada, K.; Yokota, H.; Ishii, N.; Yoshida, A., Transforming Growth Factor-beta Signaling Cascade Induced by Mechanical Stimulation of Fluid Shear Stress in Cultured Corneal Epithelial Cells. Investigative ophthalmology \& visual science 2016, 57 (14), 6382-6388; (b) Maeda, T.; Sakabe, T.; Sunaga, A.; Sakai, K.; Rivera, A. L.; Keene, D. R.; Sasaki, T.; Stavnezer, E.; Iannotti, J.; Schweitzer, R.; Ilic, D.; Baskaran, H.; Sakai, T., Conversion of mechanical force into TGF- $\beta$-mediated biochemical signals. Current biology : $C B$ 2011, 21 (11), 933-941.

24. Brown, J. C.; Rhim, A. D.; Manning, S. L.; Brennan, L.; Mansour, A. I.; Rustgi, A. K.; Damjanov, N.; Troxel, A. B.; Rickels, M. R.; Ky, B.; Zemel, B. S.; Courneya, K. S.; Schmitz, K. H., Effects of exercise on circulating tumor cells among patients with resected stage I-III colon cancer. PloS one 2018, 13 (10), e0204875-e0204875.

25. (a) Pitcher, G. M.; Henry, J. L., Nociceptive response to innocuous mechanical stimulation is mediated via myelinated afferents and NK-1 receptor activation in a rat model of neuropathic pain. Experimental neurology 2004, 186 (2), 173-97; (b) Dhandapani, R.; Arokiaraj, C. M.; Taberner, F. J.; Pacifico, P.; Raja, S.; Nocchi, L.; Portulano, C.; Franciosa, F.; Maffei, M.; Hussain, A. F.; de Castro Reis, F.; Reymond, L.; Perlas, E.; Garcovich, S.; Barth, S.; Johnsson, K.; Lechner, S. G.; Heppenstall, P. A., Control of mechanical pain hypersensitivity in mice through ligand-targeted photoablation of TrkB-positive sensory neurons. Nature Communications 2018, $9(1), 1640$.

26. Liang, X.; Huang, X.; Zhou, Y.; Jin, R.; Li, Q., Mechanical Stretching Promotes Skin Tissue Regeneration via Enhancing Mesenchymal Stem Cell Homing and Transdifferentiation. Stem cells translational medicine 2016, 5 (7), 960-9. 
27. Barnes, L. A.; Marshall, C. D.; Leavitt, T.; Hu, M. S.; Moore, A. L.; Gonzalez, J. G.; Longaker, M. T.; Gurtner, G. C., Mechanical Forces in Cutaneous Wound Healing: Emerging Therapies to Minimize Scar Formation. Advances in wound care 2018, 7 (2), 47-56.

28. Scimia, M. C.; Hurtado, C.; Ray, S.; Metzler, S.; Wei, K.; Wang, J.; Woods, C. E.; Purcell, N. H.; Catalucci, D.; Akasaka, T.; Bueno, O. F.; Vlasuk, G. P.; Kaliman, P.; Bodmer, R.; Smith, L. H.; Ashley, E.; Mercola, M.; Brown, J. H.; Ruiz-Lozano, P., APJ acts as a dual receptor in cardiac hypertrophy. Nature 2012, 488 (7411), 394-8.

29. Feng, H.; Gerilechaogetu, F.; Golden, H. B.; Nizamutdinov, D.; Foster, D. M.; Glaser, S. S.; Dostal, D. E., p38alpha MAPK inhibits stretch-induced JNK activation in cardiac myocytes through MKP-1. International journal of cardiology 2016, 203, 145-55.

30. Tse, J. M.; Cheng, G.; Tyrrell, J. A.; Wilcox-Adelman, S. A.; Boucher, Y.; Jain, R. K.; Munn, L. L., Mechanical compression drives cancer cells toward invasive phenotype. Proceedings of the National Academy of Sciences 2012, 109 (3), 911.

31. Wilkins, J. R.; Pike, D. B.; Gibson, C. C.; Li, L.; Shiu, Y.-T., The interplay of cyclic stretch and vascular endothelial growth factor in regulating the initial steps for angiogenesis.

Biotechnology progress 2015, 31 (1), 248-257.

32. Simonetto, D. A.; Yang, H. Y.; Yin, M.; de Assuncao, T. M.; Kwon, J. H.; Hilscher, M.; Pan, S.; Yang, L.; Bi, Y.; Beyder, A.; Cao, S.; Simari, R. D.; Ehman, R.; Kamath, P. S.; Shah, V. H., Chronic passive venous congestion drives hepatic fibrogenesis via sinusoidal thrombosis and mechanical forces. Hepatology (Baltimore, Md.) 2015, 61 (2), 648-59.

33. Gao, S.; Carson, J. A., Lewis lung carcinoma regulation of mechanical stretch-induced protein synthesis in cultured myotubes. American journal of physiology. Cell physiology 2016, 310 (1), C66-79.

34. Cabrera-Benítez, N. E.; Parotto, M.; Post, M.; Han, B.; Spieth, P. M.; Cheng, W.-E.; Valladares, F.; Villar, J.; Liu, M.; Sato, M.; Zhang, H.; Slutsky, A. S., Mechanical stress induces lung fibrosis by epithelial-mesenchymal transition. Critical care medicine 2012, 40 (2), 510-517.

35. Dupont, S.; Morsut, L.; Aragona, M.; Enzo, E.; Giulitti, S.; Cordenonsi, M.; Zanconato, F.; Le Digabel, J.; Forcato, M.; Bicciato, S.; Elvassore, N.; Piccolo, S., Role of YAP/TAZ in mechanotransduction. Nature 2011, 474 (7350), 179-83.

36. Faisy, C.; Pinto, F. M.; Le Guen, M.; Naline, E.; Grassin Delyle, S.; Sage, E.; Candenas, M. L.; Devillier, P., Airway response to acute mechanical stress in a human bronchial model of stretch. Critical care (London, England) 2011, 15 (5), R208.

37. Nonomura, K.; Woo, S.-H.; Chang, R. B.; Gillich, A.; Qiu, Z.; Francisco, A. G.; Ranade, S. S.; Liberles, S. D.; Patapoutian, A., Piezo2 senses airway stretch and mediates lung inflation-induced apnoea. Nature 2016, 541, 176.

38. Sonomura, K.; Okigaki, M.; Kimura, T.; Matsuoka, E.; Shiotsu, Y.; Adachi, T.; Kado, H.; Ishida, R.; Kusaba, T.; Matsubara, H.; Mori, Y., The kinase Pyk2 is involved in renal fibrosis by means of mechanical stretch-induced growth factor expression in renal tubules. Kidney international 2012, 81 (5), 449-57.

39. Cachat, F.; Lange-Sperandio, B.; Chang, A. Y.; Kiley, S. C.; Thornhill, B. A.; Forbes, M. S.; Chevalier, R. L., Ureteral obstruction in neonatal mice elicits segment-specific tubular cell responses leading to nephron loss. Kidney international 2003, 63 (2), 564-75.

40. Patel, V. S.; Chan, M. E.; Pagnotti, G. M.; Frechette, D. M.; Rubin, J.; Rubin, C. T., Incorporating Refractory Period in Mechanical Stimulation Mitigates Obesity-Induced Adipose Tissue Dysfunction in Adult Mice. Obesity (Silver Spring, Md.) 2017, 25 (10), 1745-1753. 41. Nelson, A. G.; Kokkonen, J.; Arnall, D. A., Twenty minutes of passive stretching lowers glucose levels in an at-risk population: an experimental study. Journal of Physiotherapy 2011, 57 (3), 173-178. 
42. Carmena, M., Flies stretch their cells to avoid a chromatin trap. J Cell Biol 2012, 199 (5), 719-21.

43. Zhang, H.; Landmann, F.; Zahreddine, H.; Rodriguez, D.; Koch, M.; Labouesse, M., A tension-induced mechanotransduction pathway promotes epithelial morphogenesis. Nature 2011, 471 (7336), 99-103.

44. Geddes, D. M.; LaPlaca, M. C.; Cargill, R. S., 2nd, Susceptibility of hippocampal neurons to mechanically induced injury. Experimental neurology 2003, 184 (1), 420-7.

45. Berrueta, L.; Muskaj, I.; Olenich, S.; Butler, T.; Badger, G. J.; Colas, R. A.; Spite, M.; Serhan, C. N.; Langevin, H. M., Stretching Impacts Inflammation Resolution in Connective Tissue. Journal of cellular physiology 2016, 231 (7), 1621-1627.

46. Klingberg, F.; Chow, M. L.; Koehler, A.; Boo, S.; Buscemi, L.; Quinn, T. M.; Costell, M.; Alman, B. A.; Genot, E.; Hinz, B., Prestress in the extracellular matrix sensitizes latent TGF- $\beta 1$ for activation. The Journal of Cell Biology 2014, 207 (2), 283-297.

47. Helle, S. C. J.; Feng, Q.; Aebersold, M. J.; Hirt, L.; Grüter, R. R.; Vahid, A.; Sirianni, A.; Mostowy, S.; Snedeker, J. G.; Šarić, A.; Idema, T.; Zambelli, T.; Kornmann, B., Mechanical force induces mitochondrial fission. eLife 2017, 6, e30292. 